\title{
A Review of Genetic Engineering in Current Aquaculture Practises
}

\begin{abstract}
Fish represent the main food protein eaten worldwide. Farming of fish has been a traditional practice in South East Asia for over 500 years, ${ }^{1}$ but with the recent collapse of major fish stocks around the globe and the increasing demand for fish, farming of fish species has turned into an intensive practice that is raising important concerns about its sustainability. With recent advances in genetics and marine biotechnology, aquaculture may undergo a further transformation with the addition of genetically modified organisms (GMOs) to farmed stocks. Genetic engineering of fish and shellfish has been under development for decades but until recently this has been restricted to research experiments. ${ }^{2}$ However, after 20 years of pressures from aquaculture and biotechnology companies, the US Food and Drug Administration (FDA) is on the verge of approving genetically modified salmon in US markets. ${ }^{3}$ This has opened major debates about the potential environmental outcomes and the possibility of approval by the global market. This article discusses the development of aquaculture over recent years with the advance of genetic engineering using salmon, 'the king of fish', as a case study.
\end{abstract}

Keywords: Aquaculture, Genetic Engineering, Atlantic Salmon, Genetically Modified Organisms, Fish, Farming
Volume 2 Issue I - 2015

\author{
Carlotta Molfese \\ Marine Biology and Ecology Research Centre, Plymouth \\ University, UK
}

Correspondence: Carlotta Molfese, Marine Biology and Ecology Research Centre, Plymouth University, Drake Circus, Plymouth PL4 8AA, UK, Tel 07796623097. Email carlotta09। I@gmail.com

Received: December 24, 2015 | Published: January 27, 2015
Abbreviations: GMO, Genetically Modified Organism; GM, Genetically Modified; GH, Growth Hormone

\section{Introduction}

Marine capture fisheries catches have been declining steadily for the past decades ${ }^{4}$ with $28.8 \%$ of fish stocks being overfished in $2011,{ }^{5}$ large predators in the world oceans have been declining at remarkable rates $^{6}$ and an increasing number of shellfish and invertebrates are being harvested to compensate for decreased fish catches. ${ }^{7,8}$ Meanwhile, aquaculture production has increased dramatically over the past 50 years reaching 90.4 million tonnes (live weight equivalent) in 2012 contributing about $49 \%$ of the fishery output for human consumption. ${ }^{5}$ Today, aquaculture is the world's fastest growing food-producing sector. Asia is the largest producer ( $90 \%$ of global production) ${ }^{9}$ and salmon is the species dominating aquaculture production worldwide with Norway and Chile being the top producers and with only six companies accounting for $40 \%$ of all farmed salmon. ${ }^{9}$ However, such remarkable outputs have been accompanied by deep transformations in farming practices. From simple fish husbandry involving raising of fish in hatcheries and then releasing it into the wild, aquaculture has now moved onto a total manipulation of fish life-cycle so that fish are reared and maintained in captivity until they are harvested for market. ${ }^{3}$ In the case of salmon, the natural cycles of migration that this formidable species has evolved over millennia are now completely eliminated.

The recent intensification of aquaculture can be compared to the intensification of agriculture in the 1950s. As for agriculture's 'Green Revolution', the so called 'Blue Revolution' generates considerable impacts on the environmental, social, and ethical spheres. As for all intensive monoculture systems, the high density of a single species in a confined habitat generates problems of diseases and parasites as well as wastes accumulation and dispersion. ${ }^{10}$ High amounts of pesticides and antibiotics are used to fight the spread of diseases and parasites with detrimental consequences for the fishes themselves, the environment as well as consumers. ${ }^{11}$ Waste accumulation from farm cages is a serious problem especially in confined habitats such as fjords and lakes that can lead to the degradation of water quality and the development of eutrophication. ${ }^{9}$ Escapees from farms and the impact of interbreeding on the genetic diversity of wild population is of great concern too. ${ }^{12}$ This is especially important when farming non-native species, as escaped individuals may establish in the new habitat causing serious ecological problems. For example, over 255,000 Atlantic salmon have been reported in the North Pacific since the 1980s..$^{13}$ Not to mention the amount of resources that such intensive practices need for the maintenance of the farm and the stock. These include industrial energy sources (oil, coal, electricity, etc.) used for the production of net pens, the running of automatic feeders, aerators and pumps, the transport of animals and juveniles and the production of feed pellets. The input in a cage farm amounts to as much as $15,000-25,000 \mathrm{kcal}$ per kilogram of reared salmon. ${ }^{14}$ Similarly, the amount of wild fish used for feeding a farmed species is highly unsustainable and put further pressure on already exploited fish populations: approximately $5 \mathrm{~kg}$ of wild fish are used for $1 \mathrm{~kg}$ of carnivorous farmed fish. ${ }^{13}$

\section{Discussion}

Some believe that marine biotechnology has the potential to reduce the environmental and economic cost of aquaculture by genetically modifying organisms. ${ }^{4}$ Although there is no authorization for commercialization so far, research into genetic engineered fish has been carried out for more than 10 years. ${ }^{3}$ The main objectives for improvements include: increase growth rate, control of reproduction and sexual differentiation, tolerance to different environmental conditions (e.g. temperature), resistance to disease and parasites and modification of behaviour (e.g. aggressiveness). ${ }^{2}$ The principal species used in bioengineering experiments are Atlantic salmon (Salmosalar), Coho salmon (Oncorhynchus kisutch), common carp (Cyprinus carpio), tilapia (Oreochromisniloticus) and channel catfish (Ictalurus punctatus). ${ }^{4}$ Transgenic salmon is on top of the list and the 
American biotechnology company Aqua Bounty Technologies Inc. is the creator of a GM salmon that may soon enter the US market. ${ }^{15}$ They created a genetic construct consisting of a promoter from the ocean pout (Zoarces americanus) coupled to a growth hormone from the Chinook salmon (Oncorhynchus tshawytscha). This GM salmon, called Aqua AdvantageÒ Salmon, can grow 5-10 times faster than its natural counterpart and therefore reaches market size in 1.5 years instead of $3 .{ }^{15}$ Transgenesis is the process of introducing an exogenous gene (transgene) from one organism to another, so that the new organism will exhibit the new trait that the transgene codes for. ${ }^{2}$ Although this technique might sound simple, it is far from so: it involves the modification of the very molecule of life, the DNA; it means crossing species barriers created by nature over evolutionary time scales. Even though this process has been made possible in recent years, we far from understand it and there are significant risks that need to be considered when altering the very foundations of life.

Genetic modification by itself can be highly risky when the outcomes cannot be predicted for certain. The insertion of a gene by chance into an unknown genome can have various outcomes that can affect not only the desirable trait but also other physiological functions such as reproduction, immune defence, nutrition and so on. ${ }^{2}$ Genes' interactions are multiple and very complex, and physiological and environmental conditions can also influence the expression of a certain gene. ${ }^{2}$ Genomic rearrangements occur randomly in nature too, but they happen to fulfil a certain role or need in the species evolution. Human understanding of genes is still very much underdeveloped, and the more knowledge is gained the more gaps are realized.

In the case of Atlantic salmon, studies have shown that the insertion of a transgene coding for a growth hormone $(\mathrm{GH})$ not only affects growth but also feed conversion efficiency, metabolic rate, head morphology, osmoregulation, sexual maturity and behavior. ${ }^{16}$ Moreover, body protein, dry matter, ash, lipid and energy content all decrease in the transgenic salmon, while body moisture (=water) increases, suggesting that all those nutritional qualities valued in fish are actually lost in GM salmon. ${ }^{17}$

Human health risks are also very high since the outcomes of a transgenesis are unpredictable and not controllable: it may alter the biochemical pathways and chemical composition resulting in allergenic or toxic characteristics. Moreover, due to the accelerated growth rate, GM salmon could also become a bio-accumulator of pollutants having less time to eliminate toxic chemicals before being harvested for the market. ${ }^{2}$ The health risk would also increase if GM fish are fed with GM crops such as soy. Some GM crops are genetically modified to be resistant to certain diseases, resistance may be transferred by horizontal gene transfer to humans too which may lead to bacterial resistance to antibiotics.

Up to 2 million salmon escape farms in the North Atlantic every year from both routine handling and large-scale accidents. ${ }^{18}$ This raises questions about the ecological sustainability of transgenic salmon. Ecological relationships between transgenic organisms and wild species are still unknown but evidence suggests that escaped fish could introduce diseases or compete for resources in the wild. ${ }^{19} \mathrm{GH}$ protein alters salmon behaviour: it increases appetite and promotes competitiveness hence GM salmon could potentially out-compete native populations for food and as they reach maturity earlier, and they could outnumber natural stocks. ${ }^{16}$ In the long-run the genetic diversity of the wild population could be affected due to crossing with transgenic individuals whose new traits may seem advantageous at first but may become detrimental for the population survival on the long run as GM salmon have reduced anti-predator response compared to their wild counterparts. ${ }^{16}$ The impacts of transgenic organisms on the entire ecosystems are still unknown because of the variability of outcomes of genetic modifications. ${ }^{19}$ Moreover, lab-based experiments and predicting models that have been used to forecast possible outcomes in a natural ecosystem cannot incorporate all the complexities of the environment and therefore have to be considered with caution..$^{20}$ AquaBounty Technologies Inc. assures the GM salmon would be raised in in-land tanks away from the sea but even landbased systems cannot guarantee $100 \%$ confinement especially with a hatchery on site because eggs and fry are so small that could be even transported in water droplets. ${ }^{2}$ Furthermore, the transport of fish from sites and the daily maintenance routine can also pose risk of dispersal. Sterilization has also been put forward as a counter-measure but it is never completely effective. ${ }^{20}$

\section{Conclusion}

With the prospect of increased production and economic profits, fish farming with the help of genetic engineering is adventuring into unknown territories. Although some believe that the introduction of GM organisms could reduce the environmental impact of aquaculture, this is highly debatable when taking into account the lack of knowledge on the possible outcomes of modifying organisms' genomes and the potential of dispersal in the wild. Most of the studies carried out with GM organisms have been performed by the producing company in laboratory conditions that do not account for environmental fluctuations and within such short time-frames ( $\sim 90$ days) that any genetic effects would not have time to manifest. ${ }^{21}$ For these reasons such experimentations are highly unrealistic and their results extremely controversial. ${ }^{21}$ The large gaps in our current knowledge on genetic modifications oblige us to adopt a precautionary approach towards this critical subject. ${ }^{22}$

\section{Acknowledgments}

None.

\section{Conflicts of interest}

None.

\section{References}

1. Eng CT, Paw JN, Guarin FY. The Environmental Impact of Aquaculture and the Effects of Pollution on Coastal Aquaculture Development in Southeast Asia. Mar Pollut Bull. 1989;20(7):335-343.

2. Le Curieux-Belfond O, Vandelac L, Caron J, et al. Factors to consider before production and commercialization of aquatic genetically modified organisms: the case of transgenic salmon. Environ Sci Policy. 2009;12(2):170-189.

3. Clausen R, Longo SB. The tragedy of the commodity and the farce of AquaAdvantage salmon. Dev Change. 2012;43(1):229-251.

4. Maclean N. Genetically modified fish and their effects on food quality and human health and nutrition. Trends Food Sci Tech. 2003;14(58):242-252

5. FAO. The State of World Fisheries and Aquaculture (SOFIA) Rome: Food and Agriculture Organization of the United Nations. 2014

6. Christensen V, Guenette S, Heymans JJ, et al. Hundred-year decline of North Atlantic predatory fishes. Fish. 2003;4(1):1-24.

7. Molfese C, Beare D, Hall-Spencer JM. Overfishing and the Replacement of Demersal Finfish by Shellfish: An Example from the English Channel. PLoS ONE. 2014;9(7):e101506. 
8. Thurstan RH, Roberts CM. Ecological Meltdown in the Firth of Clyde, Scotland: Two Centuries of Change in a Coastal Marine Ecosystem. PLoS ONE. 2010;5(7):e11767.

9. Schlag AK. Aquaculture: an emerging issue for public concern. J Risk Res. 2010;13(7):829-844.

10. Costello MJ. How sea lice from salmon farms may cause wild salmonid declines in Europe and North America and be a threat to fishes elsewhere. Proc R Soc B. 2009;276.

11. Cabello FC. Heavy use of prophylactic antibiotics in aquaculture: a growing problem for human and animal health and for the environment Environ Microbiol. 2006;8(7):1137-1144.

12. Volpe J. Super-unnatural BC: Atlantic salmon in British Columbia Vancouver: David Suzuki Foundation. 2001.

13. Naylor RL, Goldburg RJ, Primavera JH, et al. Effect of aquaculture on world fish supplies. Nature. 2000;405:1017-1024.

14. Folke C, Kautsky N. Aquaculture with its Environment: Prospects for Sustainability. Ocean Coast Manage. 1992;17(1):5-24.

15. Forabasco F, Lohmus M, Rydhmer L, et al. Genetically modified farm animals and fish in agriculture: a review. Livest Sci. 2013;153(1-3):1-9.

16. Hallerman EM, McLean E, Fleming IA. Effects of growth hormone transgenes on the behavior and welfare of aquacultured fishes: A review identifying research needs. Appl Anim Behav Sci. 2007;104(3-4):265294.
17. Cook JT, McNiven MA, Richardson GF, et al. Growth rate, body composition and feed digestibility/conversion of growth-enhanced transgenic Atlantic salmon (Salmo salar). Aquaculture. 2000;188(12):L15-L32.

18. McGinnity P, Prodohl P, Ferguson A, et al. Fitness reduction and potential extinction of wild populations of Atlantic salmon, Salmo salar, as a result of interactions with escaped farmed salmon. Proc R SocLond B. 2003;270(1532):2443-2450.

19. Kapuscinski AR, Hallerman EM. Transgenic fish and public policy: anticipating environmental impacts of transgenic fish. Fisheries. 1990;15(1):2-11.

20. Stokstad E. Engineered Fish: Friend or Foe of the Environment? Science. 2002;297(5588):1797-1799.

21. Seralini GE, Cellier D, de Vendomois JS. New Analysis of a Rat Feeding Study with a Genetically Modified Maize Reveals Signs of Hepatorenal Toxicity. Arch Environ Contam Toxicol. 2007;52(4):596-602.

22. Richmond RH. Environmental protection: applying the precautionary principle and proactive regulation to biotechnology. Trends Biotechnol. 2008;26(8):460-467. 